\title{
Making Use of Children Storybooks in Designing Writing Activities for Children Learning EFL
}

\author{
Winti Ananthia \\ Universitas Pendidikan Indonesia-Kampus Cibiru, \\ Jl. Raya Cibiru Km. 15, Bandung, Indonesia \\ Corresponding e-mail: winti@upi.edu
}

\begin{abstract}
Writing is said as the most difficult skill to be taught. Teachers often simply conducted free writing activity and ask students to produce paragraphs of writing piece. Therefore, writing activity is often unachievable for Indonesian elementary school students as beginner English learners. This paper presents part of a research project on a course preparing Indonesian student teachers who were candidates of elementary school English teachers. This paper aims to share how elementary school student teachers design meaningful and fun writing activities from children storybooks. The study was conducted in 'Writing and Dictation for Elementary School' course, in an English Concentration of Elementary School Teacher Training (henceforth PGSD, Pendidikan Guru Sekolah Dasar). The project-based learning was implemented in the course. It was conducted in a whole semester, consisting of 16 meetings. The project was designing writing activities for elementary school students based on children storybooks. There were 32 of $7^{\text {th }}$ semester of PGSD students included in this study. They were asked to choose, sort, select, and analyse some children storybooks based on the characteristics of elementary school students. About 50 books were chosen, 32 books were sorted and then selected into 16 books. The books were analysed using six qualities of effective writing called "the $6+1$ traits of writing". The PGSD students were then asked to design writing activities for children. Practically, the project has shown how to make use of those children books in the writing class for children learning EFL. Qualitative data analysis includes a field note, the student teachers' children storybook review and report, and the designed writing activities for elementary school students. The result of the study shows that PGSD students have demonstrated their ability to design achievable, meaningful and fun writing, from controlled, guided, to free activities for children learning English in Indonesian elementary school.
\end{abstract}

Keywords: children storybooks, EFL, English for Young Learners, writing activity design

\section{INTRODUCTION}

English is considered important in a more globalized era as one of indicators for personal and professional capabilities in the 21 st century (Trilling \& Fadel, 2009). Therefore, to be able to participate in a global society, it is highly recommended for a person to have English competency. In Indonesia, English is considered as a Foreign Language (FL) as it is not used officially in daily life. Consequently, some parents who realise the importance of English for their children's future success request the teaching of English to be started in the preschool level (Ananthia, Harun \& Silawati, 2015;

Yuliariatiningsih, Ananthia \& Yanthi, 2013) to lengthen the exposure towards English. It also happens in other Asian countries such as Korea (Lee, J. H., 2012) where parents play important roles to demand EFL teaching started in early years of education.

In Indonesian elementary school level, although English is not a compulsory subject, the parents' 
demand on the teaching of English keeps continues. It makes many schools, especially in urban areas; allocate some slots of English among other subjects in school schedule. However, the practice of English language teaching to the elementary school students is not without problem. English is usually taught by memorising set of vocabularies which leads to a not meaningful English learning, such as presenting a very textbook-based activity (Freire \& Filho, 2015). This situation is worse by having English teacher who is barely speaking in English during the English class (Moon, 2005).

In terms of language skills, English, like other language, is generally consisted of four language skills, namely, listening, speaking, reading and writing. It is expected that elementary school children can be exposed to English to develop the four language skills. However, teaching writing is often avoided especially in English classes in most Indonesian elementary school. Even though when teaching writing is conducted, the activities are far from considering elementary school children's characteristics. The children are often asked to just copy some sentences from textbooks or from the teachers' writing on board in front of the classroom. Sometimes, teachers just simply ask the children to write a paragraph of their experiences, without explaining how to do it.

Based on the phenomenon that often happens in EFL classes in Indonesian elementary school, it is important for teacher candidates, who will teach English to elementary school children in the future, to be able to conduct proper writing activities. This paper is a description of activity as one of the parts in 'Writing and Dictation for Elementary School' course in an English concentration of PGSD. The student teachers joining the course were asked to review and then analyse children's literature based 'the $6+1$ traits of effective writing' as proposed by Paquette (2007) before designing writing activities for elementary school children. This paper aims to describe how elementary school student teachers design writing activities from children storybooks that suits the characteristics of elementary school children within the course aforementioned. Previous studies related to teaching writing activities often conducted in first language or second language setting. This paper attempts to give exemplar towards teaching writing to children in EFL setting.

\section{THEORY AND METHOD}

\section{$2.1 \quad$ Literature Review}

Working with children learning English as a Foreign Language (EFL) in Indonesian elementary classroom can be both a rewarding and demanding experience. Writing is believed as the most difficult language skill even in the native language. Teaching writing in a foreign language is a challenging experience for most teachers since writing is considered as a difficult thing even in native language (Orr, 1999; Paul, 2007). Writing is viewed as the most difficult one compared to other language skills since there are other elements included in writing, such as vocabulary, spelling, grammar, handwriting quality and punctuation (Harmer, 2004; Latham, 2002). By considering the view, writing, especially in EFL context is not recommended to be conducted in early stages such as in Korea and Austria (Brewster, Ellis \& Girrad, 2002).

In Indonesian elementary school, teaching English is focused on mastering simple communication suitable for the child world. Thus, learning English is limited to speaking and listening, while reading and writing are not really emphasised (Sutarsyah, 2004, p. 285). On the other hand, there is a different view that states the need to have a balance of skills between the four language skills, which includes writing skill. It is believed that being able to read and write in the target language enables an EFL learner to speak more communicatively (Paul, 2007). In Taiwan, children are expected to focus on writing in the foreign language class, sometimes even at the kindergarten stage (Brewster, et al., 2002, p. 119). Writing activity is conducted with children because written products easily provide a visible sign of children's effort as well as teachers'. Therefore, it is important for teachers to design achievable and fun writing activities.

Teacher often tends to avoid writing activity, or simply asks for students' writing product instead of developing the students' writing skill. Thus, to set achievable writing activities in EFL classes, teachers need to consider variables that influence students learning, such as age, their first language and their personal proficiency in spoken language. Working with young children, teacher should focus more on their fine motor skill during writing activities, such as how they hold pencils, handwriting speed and control the forming letter (Linse, 2005). Thus, the purpose of teaching writing for young EFL learners is within the area of mastering the Roman alphabet, copying, handwriting, spelling, and forming basic sentence (Tandy \& Howell, 2008; Harmer, 2004; Loannou-Georgiou \& Pavlou, 2003). 
On the other hand, based on the discussion in the first weeks with the PGSD students included in the study, most of them perceived that teaching writing would be difficult to be conducted with Indonesian children in EFL setting since the children still have limited English. The perception was related to their own experiences during elementary school, that teachers often asked them to produce paragraph(s) of writing pieces without having through the process how to compose one(s). Therefore, writing in English in elementary school EFL setting often regarded as too complicated to be realised. At the beginning, the PGSD students did not have any ideas that writing activities could be conducted in a simpler way, integrated with fun activities such as drawing and colouring pictures, writing simple letter and composing simple sentences related to a storybook.

Regarding the fun way in teaching EFL to children, Garvie (1990), has convinced some experts in Teaching English to Young Learner (TEYL) field (such as Pinter, 2006; Brewster et al., 2002; Phillips, 1993; and Halliwell, 1992) about the employment of story as an effective methodology. Furthermore, the beneficial use of story in the context of EFL teaching is acknowledged in English language teaching (Brewster et al., 2002; Erkaya, 2005). Teaching EFL through stories has widely used as one of the effective ways to develop children's language skills (such as Kalantari \& Hashemian, 2016; Freire \& Filho, 2015; Yildirim \& Torun, 2014; Lee, S., 2012; Ahmad, 2012; Harrasi, 2012).

One of the ways of using stories in teaching EFL is in the form of storybook (Hsiu-Chih, 2008). Although storybook is believed to be able to develop children's' four language skills, most of previous research investigated the using of children's literature are mainly focused on developing listening or reading skills. Some of them also discussed the using of storybook to enhance children's speaking skill. However, only few researches focus on the developing of children's writing skill through storybook. Therefore, this study is initiated to focus on how to conduct writing activity for children in EFL setting.

To enhance children's writing through storybook, high quality children's literature should be used. That statement is relevant with the view that a good writer is a good reader. In developing children's writing skill through storybooks, Paquette (2007) recommended "the $6+1$ traits of effective writing". The traits refer to ideas, organisation, word choice, voice, sentence fluency, and conventions. The +1 refers to publication of the written product. It is contended that storybook serves as exemplars of good writing. Therefore, by being exposed to good quality of storybooks, children are expected to be able to develop their writing skill.

\subsection{Method}

The selected classroom activities reported and analysed in this article were drawn up in 2015 for a group of $327^{\text {th }}$ semester students of PGSD. They were elementary school teacher candidates who were asked to design writing activities for elementary school students. The activities were based on 16 selected children storybooks. This group was having 150-minute course of "writing and dictation for elementary school' a week. For the first half semester, the student teachers were discussing theories on how to teach writing to elementary school students. In the second half semester, after the mid semester test, they started the project designing writing activities for elementary school students based on children storybooks which is the focus of this article. The study employed the descriptive qualitative method. Qualitative data analysis includes a field note, the student teachers' children storybook reviews and reports, and the designed writing activities for elementary school students. This method is selected to obtain the picture of the process how student teachers of PGSD English Concentration design writing activity by analysing six qualities of effective writing from children storybooks as recommended by Paquette (2007).

\section{FINDINGS AND DISCUSSION}

\subsection{The Procedures of the Project}

After discussing theories on how to teach writing to children in the first half of the semester, the next activity was the project designing writing for elementary school students based on the selected children storybooks. The first step of this activity was choosing children storybooks. The student teachers were asked to choose any English children storybooks to be brought into class discussion. Some of the books were written by overseas authors while some others by Indonesian authors.

It was quite difficult to get high quality English children's literature in Indonesia, since imported books were expensive, while local English books often had unnatural English sentences since they were simply translated from Bahasa Indonesia. Therefore, PGSD student's teachers were asked to either borrow the books from libraries in Bandung 
area or bought affordable used books for the class discussion.

There were about 50 books chosen. The student teachers were asked to sort 32 out of 50 books which they think were the most suitable for elementary school student. Each of them was responsible to review one book.

The next stage of the activity was pair work. In pairs, the student teachers discussed their book reviews. They also analysed the books based on Paquette's six qualities of effective writing. In this pair work discussion, they had to decide one book between two, to be further explored for elementary school writing activity. Thus, the in-pairs discussion activity had resulted to the selection of 16 children storybooks to be further explored.

\subsection{The Six Qualities of Effective Writing: The Selected Children Storybooks}

Although a storybook could be strong in all six traits, a book could have one particular strong trait for study (Paquette, 2007). Having selected 16 children storybooks, the student teachers were asked to identify one particular trait of each book. This stage was quite challenging since the PGSD students had difficulties in determining which particular trait the book carried out. This happened since they only referred to Paquette's (2007) article in identifying the books. Thus, they came up with at least two traits for a book and five traits, the most traits that were identified from a book. This section explores the six traits identified from the 16 selected children storybooks.

\subsubsection{The Trait of Ideas}

The trait of ideas emphasises clear and focused message in a story. From the 16 selected storybooks, all of the books were identified to have this trait of ideas. All of the book were said to have this trait since all of them have ideas to talk about as the heart of the story (Paquette, 2007). For example, book \#9 was identified as having traits of ideas, talking about a little giraffe named Jerry who thought the moon as a giant butter cookie. He tried many ways to reach and have the cookie.

Meanwhile, book \#1 was identified for its traits of ideas which described a group of worried farm animals about a new animal being brought to the farm. They were worried that the new animal would take over their job in the farm. Since all of the selected storybooks had central message, they were identified to have ideas as one of the strong traits.

\subsubsection{The Trait of Organisation}

A book is considered to have strong trait of organisation when a reader could easily follow the beginning, middle and end of the story (Paquette, 2007). Ten books were identified to have trait of organisation. Book \#6 is an example to have this trait. It was identified to have clear beginning, middle and ending part. The story begins when Hello Kitty and friends came to a class, learn the things during the lesson until it finished.

\subsubsection{The Trait of Voice}

The trait of voice obviously appears when readers able to feel what the writer feels (Paquette, 2007). Six out of 16 books were identified as having trait of voice. Book \#12 is an example which has this trait. The book tells about a journey of two stars go down to the earth and learn about animals.

\subsubsection{The Trait of Word Choice}

A children storybook is considered to have the trait of word choice when everyday words are used in creative ways (Paquette, 2007). From 16 selected books, PGSD student teachers identified two books to have this trait. Book \#4 was reported to have this trait when the author of this book creatively chose words that have identical sound (rhyme). Moreover, since this book is bilingual, written in English and Bahasa Indonesia, the author is able to consistently keep the rhyme in both languages.

Book \#3 was identified to also have trait of word choice. The book was considered to have this trait since the words that the writer wants to get known by the reader was printed in bold, coloured, waved, and bigger size. However, PGSD student teachers analysing this book did not make any further clarification whether or not the words were used creatively by the writer of the book.

\subsubsection{The Trait of Sentence Fluency}

Sentence fluency appears in a storybook when the book promotes the flow of language where readers could chime in, e.g. in a form of repeated choruses (Paquette, 2007). Six out of 16 books were identified for this trait. Book \#5 is an example of this trait. In this book, a boy was playing hide and seek with many kinds of dinosaurs. Some sentences and 
phrases were repeated in the story, such as "Who's that hiding under...?" or "Who's that hiding inside...?" When the dinosaur was found, one by one, the boy shouted, "Found you!" Those repeated sentences and phrases are believed to be able to develop children's fluency.

\subsubsection{The Trait of Convention}

A book with the trait of convention emphasises the correctness of spelling, punctuation, capitalisation, and grammar. Although eight PGSD student teachers claimed that four books were identified to have this trait, none of the books really emphasise the convention in writing. The student teachers only argued that the book showed a good example of applying correct spelling, punctuation, capitalisation, and grammar. If the argument is taken into the consideration, of course all of the 16 selected children storybooks would have this trait. Therefore, after further discussion regarding to this matter, no selected books identified having the trait of convention.

Table 1 The 16 Selected Children Storybooks Traits

\begin{tabular}{cc}
\hline Traits & \multicolumn{1}{c}{ Identified Selected Books } \\
\hline Ideas & \multicolumn{1}{c}{ All the 16 selected books } \\
Organisation & $\begin{array}{l}\text { Book \#1, \#4, \#6, \#7, \#8, \#9, \#10, } \\
\text { B13, \#16 }\end{array}$ \\
Voice & Book \#1, \#7, \#8,\#12,\#15,\#16 \\
Word Choice & Book\#3 and \#4 \\
Sentence Fluency & Book\#1,\#2,\#5,\#10,\#11,\#14 \\
Convention & - \\
\hline
\end{tabular}

\subsection{Writing Activities for Children}

There are three kinds of writing activities in the language classroom, namely, controlled, guided, and free activities (Tandy \& Howell, 2008; Harmer, 2004; Latham, 2002). After identifying the traits of the 16 selected children storybooks, the next stage was designing writing activities for elementary school students. PGSD student teachers designed one writing activity from each of the selected book. Therefore, 16 writing activities were designed. The activities are varied from controlled, guided, to free writing activities.

\subsubsection{Controlled Writing Activities}

Controlled writing activity is very useful for beginner learners, especially in the context of EFL (Harmer, 2004; Latham, 2002) to help them to put down words on paper (Elturki, 2013). There were eight controlled writing activities produced. The activities were classified into three kinds of activity. The first one is gap filling activities. Six out of eight activities were classified into gap filling (book \#1, $\# 2$, \#5, \#6, \#8, \#10,\#12, and \# 15). Through this kind of activity, elementary school students could practise their spelling as one of writing elements.

The second was tracing activity (book \#6). This activity is very helpful for young learners where they can practise their eyes-hand coordination as well as familiarise themselves into English words. The last kind of activity classified into controlled writing activity was sentence arrangement (book \#15). By having this kind of activity, elementary school students have the opportunity to recount the story from the book in a more secure way since they are given sentences choices.

\subsubsection{Guided Writing Activities}

Guided writing activity is sometimes viewed as the same thing as controlled one (Elturki, 2003). However, in guided writing, students start to develop their independence in writing, where teacher can start to lessen the control. Therefore, it is not only put words down on paper, but more writing strategies are applied. In this project, PGSD student teachers produce four guided writing activities (book $\# 9$, \#11, \#14 and \#16). For example, book \#9 asks elementary school students to think of and write what tools can be used by Jerry to reach the giant butter cookie in the sky along with the reasons. The students are given prompts of how they can compose their writing by being given the beginning of the words, for example, "I choose ...., because...".

\subsubsection{Free Writing Activities}

In free writing activities, students are expected to let their ideas flow freely on the paper. This kind of activity is suitable for students who are already comfortable with controlled and guided writing activities. The project produced four writing activities that are classified into free writing activity (book \#3, \#4, \#7 and \#13). Three of them develop students' ability in composing descriptive text. For example, the main character in book \#3 was an inventor. From the story, the readers are asked to 
invent a tool and write the description of how the tool works. Meanwhile, the other one (book \#13) asks elementary school students to write a procedure of how to make their favourite drinks.

\subsubsection{After the Course}

At the end of the 'Writing and Dictation for Elementary School' course, the PGSD students are more aware that writing activities with children in Indonesian context is accomplishable. Storybooks could be employed to design achievable, fun and meaningful writing activities for children in EFL setting.

\section{CONCLUSIONS}

The project-based learning implemented in the 'writing and dictation for elementary school' course has inspired PGSD student teachers to create a more authentic and set achievable writing activities derived from good quality of children storybooks. After the project, they realise that writing activities for children as the beginner English learners can be conducted from a simple one such as drawing pictures and writing a letter. Although it is still far from perfect, this project has initiated PGSD students, as future teachers, to demonstrate their ability to design meaningful and fun writing activities ranged from controlled, guided, to free writing activities for children learning English in Indonesian elementary school. More exposure to more good-quality of children storybooks is needed to develop PGSD students' skill in designing writing activity for children with different range of English ability in Indonesian EFL context.

\section{ACKNOWLEDGEMENTS}

This research was partially supported by Elementary School Teacher Training (PGSD) study program of Universitas Pendidikan Indonesia (UPI). I would like to extend my biggest gratitude to the English Concentration students in the academic year of 2015-2016 who were involved in this study.

\section{REFERENCES}

Ahmad, A. (2012). Use of short stories as a tool of teaching reading in English as a foreign language. Journal of Educational Research. (15)2, 72-83.
Ananthia, W., Harun, C. A. \& Silawati, E. (2015). The analysis of teacher's talk in teaching English to children at Indonesian kindergarten. A paper presented at Seminar Tahunan Linguistik (SETALI) 2015. A proceeding.

Brewster, J., Gail Ellis and Denis Girard. (2002).

The Primary English Teacher's Guide. London: Penguin.

Elturki, E. (2013). Controlled writing: An effective traditional practice for developing ELLs' composition. Humanising Language Teaching. 15(2).

Erkaya, O. R. (2005). Benefits of using short stories in the EFL context. Asian EFL Journal. 8, 1-13.

Freire, N. \& Filho, M. (2015). Body, education and children's literarture: an experience with a group of $6^{\text {th }}$ grade students of English as a foreign language. Procedia - Social and Behavioral Sciences 174, 1146-1150.

Garvie, E. (1990). Story as vehicle: teaching English to young children. Clevedon/Philadelphia: Multilingual Matters.

Halliwell, S. (1992). Teaching English in the primary classroom. New York: Longman.

Harmer, J. (2004). How to Teach Writing. Malaysia: Pearson Education Limited.

Harrassi, K. T. S. A., (2012). Using Stories in English Omani Curriculum. English Language Teaching. 11(5), 51-59.

Hsiu-Chih, S. (2008). The value of English picture story books. ELT Journal, 62(1), 47-55.

Kalantari, F. \& Hashemian, M. (2015). A storytelling approach to teaching English to young EFL Iranian learners. English Language Teaching. 9(1), 221-234.

Latham, D. (2002). How children learn to write. California: Paul Chapman Publishing.

Lee, J. H. (2012). Reassessment of English-only approach in EFL context in view of young learners' attitudes, language proficiency, and vocabulary knowledge. Multilingual Education. 2 (5), 1-11.

Lee, S. (2012). Storytelling supported by technology: An alternative for EFL children with learning difficulties. TOJET: The Turkish Online Journal of Educational Technology. (11)3. 297-307.

Linse, C. T. (2005). Practical English language teaching: Young learners. New York: McGraw-Hill.

Luannou-Georgiou, S. \& Pavlou, P. (2003). Assessing young learners. Oxford: Oxford University Press.

Moon, J. (2005). Children learning English. London: Macmillan Heinemann. 
Orr, J. K. 1999. Growing up with English. Washington DC: Office of English Language Program, US Department of State.

Paquette, K. R. (2007). Encouraging primary students' writing through children's literature. Early Childhood Education Journal, 35(2), 155-165.

Paul, D. (2007). Teaching English to children in Asia. Hongkong: Pearson Longman.

Phillips, S. (1993). Young learners. Oxford: Oxford University Press.

Pinter, A. (2006). Teaching young language learners. Oxford: Oxford University Press.

Sutarsyah, C. (2004). Designing an "English for Young Learners" course as a part of English Department Curriculum. In B. Y. Cahyono \& U. Widianti (Eds.), The tapestry of English language teaching and learning in Indonesia. Malang: State University of Malang Press.

Tandy, M. and Howell, J. (2008). Creating writers in the primary classroom. New York: Routledge.

Trilling, B. \& Fadel, C. (2009). 21 st century skills: Learning for life in our times (1st ed.). United States of America: Jossey-Bass A Wiley Imprint.

Yildirim, R. \& Torun, F. P. (2014). Exploring the value of animated stories with young English language learners. TOJET: The Turkish Online Journal of Educational Technology. (13)4. 4760.

Yuliariatiningsih, M. S., Ananthia, W. \& Yanthi, N. (2013). The Application of picture-mapping method in storytelling to develop young learners' English vocabulary mastery. International Journal of Teacher Education (IJTE) UPSI-UPI. 1, 104-108.

\section{CHILDREN'S STORYBOOKS ANALYSED IN THE PROJECT}

\#1 Benjamin, A. H. \& Chapman, J. (2003). Baa! Moo! What we will do?. London: Little Tiger Press.

\#2 Maharani. (2009). Cleo and Cloe's colourful day. Bandung: Erlangga.

\#3 Gallo, T. (2013). Cloudy with a chance of meatballs 2: The greatest inventor of all time Flint Lockwood series. Simon Spotlight.

\#4 Abqary, I. (2013). Dream shoes. Noura Books.

\#5 Whybow, I. \& Reynolds, A. (2004). Harry and the dinosaurs play hide and seek. The Penguin Group.
\#6 Sanrio Co. Ltd. (2009). Hello Kitty Alphabet Part 2.

\#7 Rylant, C. (2011). Henry and Mudge and the bedtime thumps. Simon and Schuster.

\#8 Wardhana, E. (2008). I love math. Bandung: Sygma.

\#9 Christiana, M. (2015). Jerry Giraffe and the giant butter cookie. Bambini-Imprint of Gramata Publishing.

\#10 Lumsum, P., Kongnuj, C. \& Japakeeya, S. (2012). Playing hide-and-seek. Dickens Publishing Ltd.

\#11 Loewen, N. (2013). Seriously, Snow White was forgetful. Capstone Imprint.

\#12 Maharani. (2009). Shimmer \& Glitter visit the zoo. Bandung: Erlangga.

\#13 Putri, W. K. (2013). Special Fruit Cockail. Bandung: DAR! Mizan.

\#14 Mackinnon, M. \& Sheppard, K. The dressing-up box. United Kingdom.

\#15 Wright, A. (1992). The hairy tree man. Oxford: Oxford University Press.

\#16 Wright, A. (1993). The prince and the spaceship. Oxford: Oxford University Press. 